\title{
Response-Surface Analysis of the Combined Effects of Exposure and Acclimation Temperatures on Filtration, Oxygen Consumption and Scope for Growth in the Oyster Ostrea edulis
}

\author{
C. D. Buxton*, R. C. Newell ${ }^{* *}$ and J. G. Field \\ Department of Zoology, University of Cape Town, Rondebosch 7700, South Africa
}

\begin{abstract}
Acclimation at $5 \mathrm{C}^{\circ}$ intervals betwe $n 5^{\circ}$ and $20^{\circ} \mathrm{C}$ was used to determine the acute effects of temperature on energy balance in the oyster Ostrea edulis (L.). Rate-temperature curves for filtration showed evidence of lateral translation, mantaining a thermal optimum above the temperature of acclimation. No significant difference was found in food assimilation efficiency over the acclimation regime, the mean value being $76.43 \pm 9.71 \% \mathrm{~S}$. D. A low metabolic rate is maintained up to an acclimation temperature of $20^{\circ} \mathrm{C}$; beyond $20^{\circ} \mathrm{C}$ however, metabolic costs rise sharply. As a result, filtration efficiency and cost of filtration both achicve a thermal optimum between $15^{\circ}$ and $20^{\circ} \mathrm{C}$. Scope for growth, as defined by the difference between assimilated ration and energy cost of metabolism, remained positive over the cntire acclimated range at the expermental ration level. Stepwise linear regression analysis of the data produced a model relating assimilated ration, oxygen consumption and scope for growth to interactions between acclimation and exposure temperatures. Maximum growth rate is predicted at an acclimation temperature $\left(T_{0}\right)$ of approximately $17^{\circ} \mathrm{C}$ and following exposure to short-term increases of temperature $\left(T_{.}\right)$to approximately $25^{\circ} \mathrm{C}$. much as might be antripated during summer in very shallow water
\end{abstract}

\section{INTRODUCTION}

Considerable attention has been paid to the significance of energy gain and expenditure in bivalve biology (for reviews see Bayne, 1976; Winter, 1977; Newell, 1979, 1980). Physiological studies included in these reviews generally have adopted a univariable approach where ecological factors have been investigated separately as independent variables; the relationship between them and a particular physiological response then is represented in two-dimensional terms. More recent studies have attempted to combine the effects of complex environmental variables on the integrated physiological response of the organism as a whole. This multidimensional approach was reviewed in 'Marine Ecology' by Alderdice (1972), and has been adopted by Widdows (1978 a,b) and Bayne and Scul-

\footnotetext{
- Port Elizabeth Museum, P.O. Box 13147, Humewood 6013, South Africa

- Institute for Marine Environmental Research, Prospect Place, Plymouth, Devon PL1 3DH, England
}

lard (1978) in studies on the mussel Mytilus edulis and the gastropod Thais lapillus.

The phenomenon of thermal acclimation has been defined by Crisp and Ritz (1967) as any non-genetic adjustment by an organism in direct response to a change in a single factor in the environment. Regulation of many biological rate functions in response to a change in temperature have been widely described in the literature (for reviews see Fry, 1947, 1971; Kinne, 1963 a,b 1970; Precht et al., 1973; Newell, 1979), but it is only comparatively recently that the independent adjustment of the components of metabolic energy balance in relation to thermal acclimation have been investigated. Following the establishment of the wellknown balanced energy equation of Winberg (1956; see also Ricker, 1968; Odum and Smalley, 1959; Petrusewicz and MacFadyen, 1970), Warren and Davis (1967) developed the concept of a 'scope for growth' which they regarded as 'the difference between the energy of the food an animal consumes and all the other utilisations and losses'. This term has since been widely used in the literature on factors controlling the growth of bivalve molluscs (Widdows and Bayne, 1971; 
Dame 1972; Bayne, 1976; Newell and Branch, 1980; see also p. 78). Such studies suggest that the ability of bivalves to adjust components of energy balance by acclimation may enhance their ability to maintain a positive scope for growth, but that outside the limits of acclimatory adjustment energy balance considerations limit their existence to a particular ecological niche.

The work reported here summarises the acute response of filtration and oxygen consumption to temperature change in small specimens of Ostrea edulis acclimated for $30 \mathrm{~d}$ at a series of temperatures between $5^{\circ}$ and $25^{\circ} \mathrm{C}$. The influence of temperature on assimilated ration and 'scope for growth' has been calculated and incorporated into a model describing the influence of temperature on energy balance in the oyster.

\section{MATERIALS AND METHODS}

Juvenile Ostrea edulis (L.) of between 8 and $12 \mathrm{~mm}$ in shell length were obtained from the Fisheries Development Corporation hatchery at Knysna, South Africa. Five groups of oysters were acclimated for $30 \mathrm{~d}$ to temperatures (Ta) of $5^{\circ}, 10^{\circ}, 15^{\circ}, 20^{\circ}$, and $25^{\circ} \mathrm{C}$ respectively in 37.5-1 aquaria containing circulating sea water. The sea water was replaced weekly, and a surplus ration of $150 \mathrm{ml}$ of a culture containing $2.5 \times$ $10^{11}$ cells $1^{-1}$ of Tetraselmis suecica (Kylin) was fed to the oysters daily. The concept of 'scope for growth' as defined by Warren and Davis (1967; see also p. 78) quantitatively equivalent in a filter-feeding bivalve to the product of filtration rate (FR) and assimilation efficiency (AE) at any one ration. Subtraction of the energy equivalent of all other utilisations and losses yields the net energetic gain or 'scope for growth' under particular ration conditions (for reviews see Bayne, 1976; Newell, 1979). Aerobic energy losses are generally measured as oxygen consumption by bivalves in aerated water, although it is recognized that other losses such as the energetic equivalent of dissolved organic matter, not accounted for by the oxygen consumption, also contribute to the balanced energy equation. In this series of experiments on oysters we have measured filtration rate (volume of water cleared; $V_{w,}\left(\mathrm{~h}^{-i}\right.$ ) assimilation efficiency and oxygen comsumption (volume of oxygen consumed at STP; $V_{02}, \mathrm{ml} \mathrm{h}^{-1}$ ) and have assessed these independently as a function of shortterm exposure temperature $\left(T_{c}\right)$ and long-term acclimation $\left(T_{d}\right)$.

Our use of 'scope for growth' as defined by Warren and Davis (1967) should be distinguished from use of the same term which appears to have been adopted subsequently by Brett $(1976,1979)$ to describe the difference between the maximum assimilated ration and the maintenance ration in salmonids. This yields an estimate of the maximum potential scope for growth' in these organisms at optimal ration levels Clearly, the 2 terms are numerically equivalent only at ration levels where the available ration is at a maximum and the maintenance metabolism is equivalent to the maintenance ration. In our view, 'scope for growth' as defined by Warren and Davis (1967) and as extensively used in studies on bivalves (Widdows and Bayne, 1971; Dame, 1972; Bayne et al., 1973; Griffiths and King, 1979; for reviews see Bayne, 1976; Newell, 1979,1980 ) is to be regarded as an index of energy balance under specific ration conditions which are often less than optimal. The index can thus be used to express the energetic gain of such organisms in relation to food availability as well as to physico-chemical environmental variables. It therefore has a descriptive validity for a wide range of suboptimal environmental conditions, including those combinations of ration and environmental variables which commonly occur under natural conditions, where scope for growth is negative and where utilisation of metabolic reserves is required to sustain short-term survival (Gabbott and Bayne, 1973; Thompson et al., 1974; Gabbott, 1975).

Oxygen consumption and filtration rates were determined over an exposure temperature range (referred to as $T_{e}$ in the text) between $5^{\circ}$ and $30^{\circ} \mathrm{C}$, following the sequence $5^{\circ}, 20^{\circ}, 15^{\circ}, 30^{\circ}, 10^{\circ}$, and $25^{\circ} \mathrm{C}$. This minimised the possibility of short-term acclimation effects occurring during the course of the experiments. At each exposure temperature 4 oysters were placed in each of 4 experimental chambers. Each chamber contained fresh, aerated sea water filtered through 0.34 $\mu \mathrm{m}$ Millipore filters. The control was set up as an experimental chamber without oysters. Five hundred $\mathrm{ml}$ open and $200 \mathrm{ml}$ closed experimental chambers were used to measure filtration and oxygen consumption respectively. After an initial equilibration period of $1 \mathrm{~h}$, a sufficiently concentrated suspension of Tetraselmis suecica was injected to bring the particle concentration in the experimental vessels to approximately $20 \times 10^{6}$ cells $1^{-1}$, a concentration which was high enough to allow several estimations of particle concentration during the course of the experiment, but which was below the threshold of pseudofaeces production. Only 1 experiment was carried out on oysters from a particular acclimation temperature per day, after which the oysters were returned to their acclimation regimes.

\section{Filtration}

Filtration was measured as a decrease in particle concentration using a Model TA II Coulter counter. 
Particle retention was assumed to be $100 \%$, and filtration rate was calculated from the standard formula (Coughlan, 1969):

$$
V_{w}\left(1 h^{-1}\right)=\frac{\left(\log _{e} N_{1}-\log _{e} N_{2}\right) V}{T}
$$

where $V_{w}=$ filtration rate; $N_{1}$ and $N_{2}=$ cell concentrations at Time 1 and Time 2 respectively; $T=$ elapsed time in hours; $V=$ volume of vessel in litres. A number of such calculations (3-5) were made to determine a mean rate for each oyster which was then corrected for standard oyster mass using the equation

$$
V_{w s}=\frac{(5.0883)^{09144}}{\left(W_{e}\right)} \cdot V_{w e}
$$

where $V_{w s}=$ corrected rate for a standard oyster of $5.0883 \mathrm{mg} ; V_{\text {we }}=$ experimentally obtained rate for an oyster of mass $W_{e} ; 0.9144 \mathrm{mg}=$ mass exponent of filtration (Buxton, 1980). Standard oyster mass was calculated as the geometric mean of all the oysters used in the study.

\section{Oxygen Consumption}

In oysters used to determine filtration rates oxygen consumption was measured over the same range of exposure temperatures. It seems likely that the rates recorded approximate to a 'routine rate' of oxygen consumption (Fry, 1947) since the minimal or 'standard rate' in other bivalves occurs during quiescence or following a period of starvation whilst the maximal or 'active rate' occurs during periods of enhanced activity such as occurs when mussels are fed following a period of starvation (Widdows, 1973b; Bayne, 1976). We have referred to the oxygen consumption during feeding as the routine oxygen consumption $\left(\mathrm{V}_{\mathrm{O}}, \mathrm{ml} \mathrm{h}^{-1}\right)$ for the oyster and other bivalves (for review see Newell and Branch, 1980). The decrease in oxygen concentration was monitored continuously, using YSI electrodes (Model 54, Yellow Springs Instrument Co. Ltd) connected to a Beckman multichannel recorder Consumption rates were corrected to a standard oyster mass $\left(V_{O_{3}} S\right.$ ) of $5.0883 \mathrm{mg}$ using the equation:

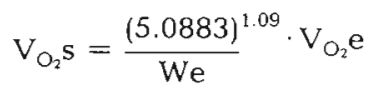

where $\mathrm{V}_{\mathrm{O}} \mathrm{e}=$ experimentally determined rate for an oyster mass $W_{e} ; 1.09=$ mass exponent of respiration (Buxton, 1980).

\section{Assimilation}

Because collection of faeces from small oysters on a quantitative basis was impractical, assimilation was estimated by the following method based on Conover (1966). Faeces were siphoned out of the aquaria over a 12-h period at intervals of less than $60 \mathrm{~min}$ which reduced leaching of organic material to the surrounding sea water. Collection was made on GFC filters which had been pre-ashed at $450^{\circ} \mathrm{C}$ for $3 \mathrm{~h}$ and washed twice with distilled water. They were then dried for 14 h at $60^{\circ} \mathrm{C}$ before being ashed at $450{ }^{\circ} \mathrm{C}$ for $12 \mathrm{~h}$. The dry mass of the ashed filters was then measured using a Mettler ME 30 microbalance. The same procedure was repeated using $5-\mathrm{ml}$ samples of Tetraselmis suecica suspension to measure the organic content of the food used. At the end of these experiments the oysters were sacrificed to determine ash-free dry mass of tissues.

\section{Modelling Methods}

The experiments carried out on Ostrea edulis yielded data on the effects of short-term exposure temperature $\left(T_{e}\right)$ and long-term acclimation temperature $\left(T_{d}\right)$ on filtration rate (FR) and oxygen consumption (OC). Because the assimilation efficiency was known, the assimilated ration ( $\mathrm{Ra}$ ) and hence 'scope for growth' $(\mathrm{Ra}-\mathrm{OC})$ could be calculated as a function of $T_{e}$ and $T_{d}$.

Stepwise multiple linear regression analysis (Allen, 1973) was used to obtain polynomial expression for both the assimilated ration $\left(Y_{1} ; R a\right)$ and the oxygen consumption $\left(Y_{2 i}\right.$ OC) in a curvilinear model of the form:-

$$
Y=a+b, X_{1}+b_{2} X_{2} \ldots \ldots \ldots
$$

where $Y=$ dependent variable (assimilated ration, $Y_{1}$ or oxygen consumption, $\left.Y_{2}\right) ; X_{1}=T_{e}$ and $X_{2}$ is $T_{0}$. Independent variables $\left(X_{1}, X_{2} ..\right)$ included linear (first degree) and curvilinear (second-fourth degree) terms for $T_{e}$ and $T_{a}$ and also interaction terms of the form $X_{1} \cdot X_{2}{ }^{n}$ and $X_{2} \cdot X_{1}{ }^{n}$, where $n=1-4$.

Four replicate data points for $Y$ were entered for each exposure temperature $\left(X_{1} ; 5^{\circ}\right.$ to $\left.30^{\circ} \mathrm{C}\right)$ and for each acclimated temperature $\left(X_{2} ; 5^{\circ}\right.$ to $\left.25^{\circ} \mathrm{C}\right)$ so that the overall number of data points for each equation was 120 . The stepwise procedure involved the progressive introduction of up to 16 of the terms, each at the $95 \%$ confidence level, to give an equation combining the fewest terms with the best overall coefficient of determination $\left(r^{2}\right)$. The regression equations obtained were then entered into a Graphics Display Package (G. D. P.) (Woodhouse Enterprises, Computer Center, University of Cape Town). From the G. D. P. the graphs were previewed via a G. D. P. Calcomp Interface and plotted as a response ( $Y$-axis) to two independent variables $T_{c}\left(X_{1}\right.$ axis) and $T_{a}\left(X_{2}\right.$ axis). The difference between the values for assimilated ration $\left(Y_{1}\right)$ and metabolic losses expressed as oxygen consumption 
$\left(Y_{2}\right)$ represents the energy equivalent of the 'scope for growth' as defined by Warren and Davis (1967; see also p. 74) and was also plotted as a multidimensional response surface as described above.

\section{RESULTS}

\section{Effect of Temperature on Filtration Rate}

The acute rate-temperature curves for filtration are shown in Fig. 1A. Four readings were taken from each chamber at 10-30 min intervals. Each point on Fig 1A

Table 1. Ostrea edulis. Percent assimilation efficiency among groups of juveniles acclimated to temperatures of $5^{\circ}, 10^{\circ}$, $15^{\circ} \mathrm{C}, 20^{\circ}$ and $25^{\circ}$ respectively, and measured in the presence of approximately $20 \times 10^{6}$ cells $1^{-1}$ of Tetraselmis suecica.

Each group of oysters was sampled $4-6$ times

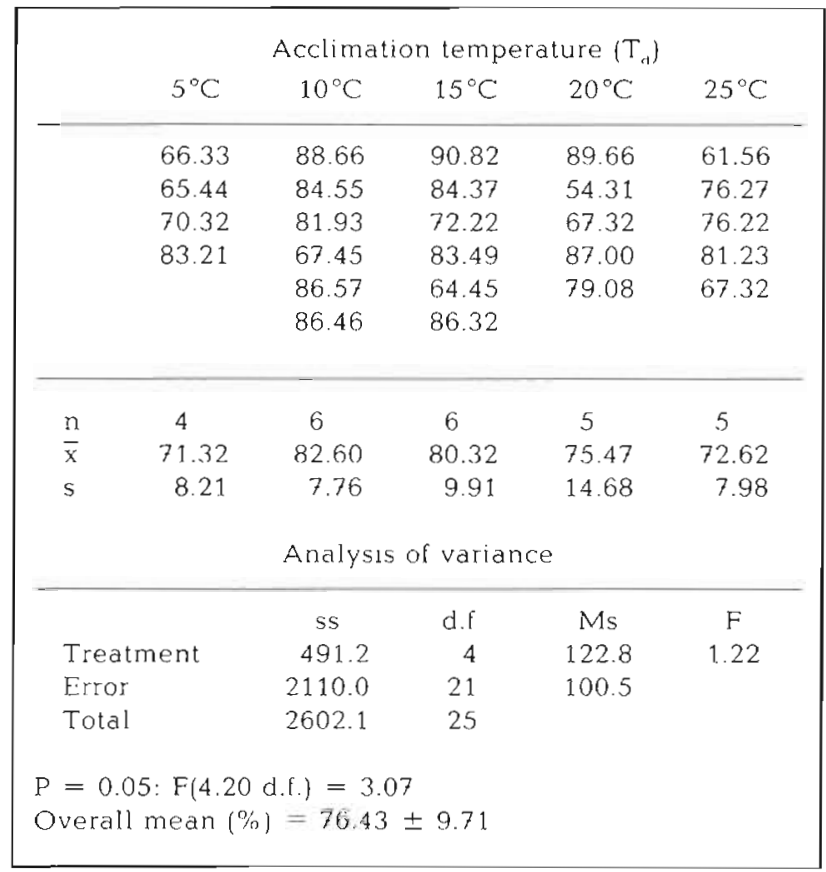

is therefore a mean of 16 determinations corrected to an oyster of standard mass.

The cold-acclimated oysters $\left(T_{d} 5\right.$ and $\left.T_{d} 10\right)$ show slow rates of filtration. In both cases peak filtration is reached at exposure temperatures higher than the acclimated temperature. The oysters acclimated to $15^{\circ} \mathrm{C}$, however, showed maximum filtration at the acclimation temperature, while those acclimated to $20^{\circ} \mathrm{C}$ show maximum filtration rates at $25^{\circ} \mathrm{C}$ (i.e. $5 \mathrm{C}^{\circ}$ above $T_{d}$ ). These results thus show evidence of a lateral translation of the RT curve for filtration (Type II of Precht, 1958). The acclimated rate-temperature curve for filtration is shown in Fig. 1B.

\section{Assimilation Efficiencies}

Assimilation efficiencies calculated for the range of acclimation temperatures are summarised in Table 1. Analysis of variance showed no significant differences between the means at the $5 \%$ level $(F=1.22, p>0.05$ for 4,20 d.f) (Zar, 1974). Therefore a mean value ( \pm S.D.) for assimilation efficiency over the entire range of acclimated temperatures was calculated as $76.43 \pm$ $9.71 \%$.

\section{Effect of Temperature on Oxygen Consumption}

As with filtration rate, oxygen consumption was calculated as the mean of 16 determinations corrected for standard oyster mass. The acute rate-temperature curves for routine oxygen consumption are shown in Fig. 2A. Rates for oysters acclimated to $5^{\circ} \mathrm{C}$ show an increase to a maximum at $15^{\circ} \mathrm{C}$ with a $Q_{10}$ of 4.19 . Oysters acclimated to $10^{\circ}, 15^{\circ}$ and $20^{\circ} \mathrm{C}$, however, show a lower increase in rate with a $Q_{10}$ of approximately 2.0 over the exposure temperature range of $5^{\circ}$ to $20^{\circ} \mathrm{C}$. At an acclimation temperature of $25^{\circ} \mathrm{C}$, however, oxygen consumption appears to be relatively
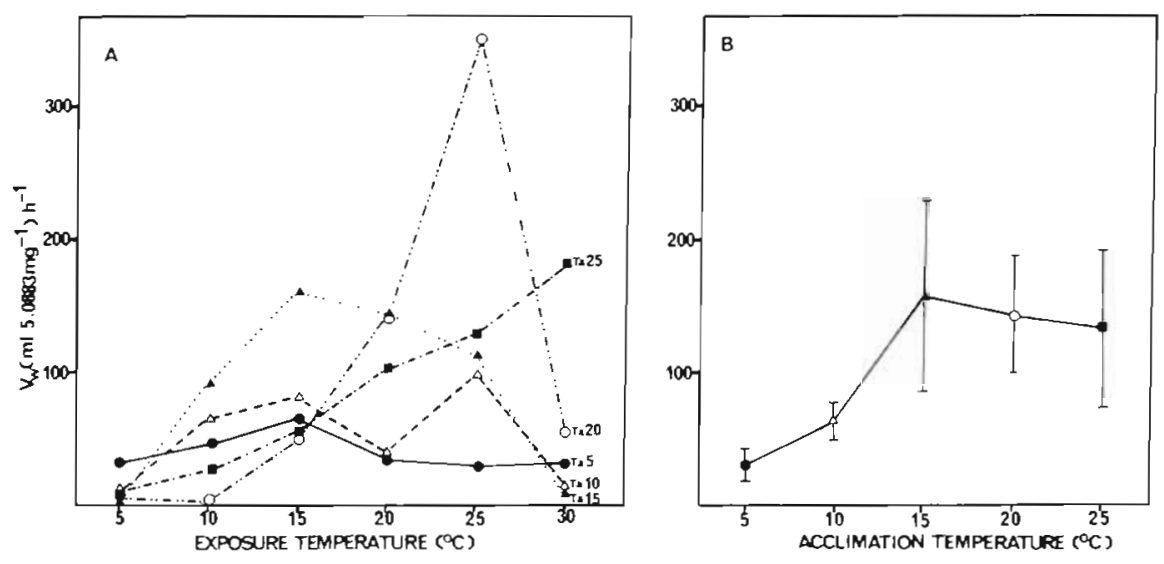

Fig. 1 Ostrea edulis. (A) Acute rate-temperature curves for clearance rates of Tetraselmis suecica, following acclimation to temperatures from $5^{\circ}$ to $25^{\circ} \mathrm{C}$. (B) Acclimated ratetemperature curve for clearance rates of Tetraselmis suecica (mean \pm 1 standard deviation) (see also Table 2) 
independent of temperature; moreover the level of the curve has shifted resulting in an increased metabolic cost over the entire temperature range.

The acclimated rate-temperature curve for routine oxygen consumption is shown in Fig. 2B. In effect modification of the RT curves maintains a relatively uniform rate of oxygen consumption at the temperature to which the oysters have been acclimated between $5^{\circ}$ and $20^{\circ} \mathrm{C}$, but metabolic costs increase dramatically between $20^{\circ}$ and $25^{\circ} \mathrm{C}$

\section{Effect of Temperature on Filtration Efficiency and Cost of Filtration}

The ratio of the volume of water cleared per volume of oxygen consumed $\left(V_{w} / V_{O_{2}}\right)$ is termed the convection requirement' (Bayne, 1976) and may be used as an index of irrigation or filtration efficiency (Newell et al., 1977; Newell and Branch, 1980). Values of the ratio obtained in this study are shown in Fig. 3. The results show that, following acclimation to $5^{\circ}$ and $25^{\circ} \mathrm{C}$, the volume of water filtered per unit oxygen consumed is relatively low over the entire range of exposure tem- peratures. Following acclimation to $10^{\circ}, 15^{\circ}$, and $20^{\circ} \mathrm{C}$, however, the ratio of $V_{w} / V_{0}$, increases rapidly in relation to increasing exposure temperature, reaching a maximum at or near the temperature to which the oysters had been acclimated (i.e. where $T_{n} \simeq T_{c}$ )

The acclimated RT curve for filtration efficiency is shown in Fig. 3B. It is clear from the figure that filtration efficiency increases from a low level at $T_{d} 5$ to a maximum at or near $T_{c} 15$ and then decreases to a low level at $T_{d} 25$. This may be explained by the fact that through $T_{d} 5$ to $T_{d} 20$ oxygen consumption is reasonably constant while the filtration rate increases with warm acclimation up to $15^{\circ} \mathrm{C}$ (Fig. 1B). The low value of $V_{w} /$ $V_{O}$, following acclimation at $25^{\circ} \mathrm{C}$ may be explained by the high rate of oxygen consumption at $25^{\circ} \mathrm{C}$, which is associated with a reduced rate of filtration.

These adjustments in the filtration rate $\left(V_{w}\right)$ and oxygen consumption $\left(V_{O_{i}}\right)$ in relation to thermal acclimation result in the energetic cost of filtration $\left(V_{O_{2}} / V_{w}\right)$ being minimal at approximately $15^{\circ} \mathrm{C}$, much as has been described in large specimens of Ostrea edulis (Newell et al., 1977). It is thus likely that maximum energetic gain, and consequent growth, can be achieved in oysters held at or near $15^{\circ} \mathrm{C}$.
Fig. 2. Ostrea edulis. (A) Acute rate-temperature curves for oxygen consumption of individuals fed Tetraselmis sueci$c a$ at acclimation temperatures between $5^{\circ}$ and $25^{\circ} \mathrm{C}$. (B) Acclimated rate-temperature curve (means \pm 1 standard doviation) for oxygen consumption (see also Table 2)
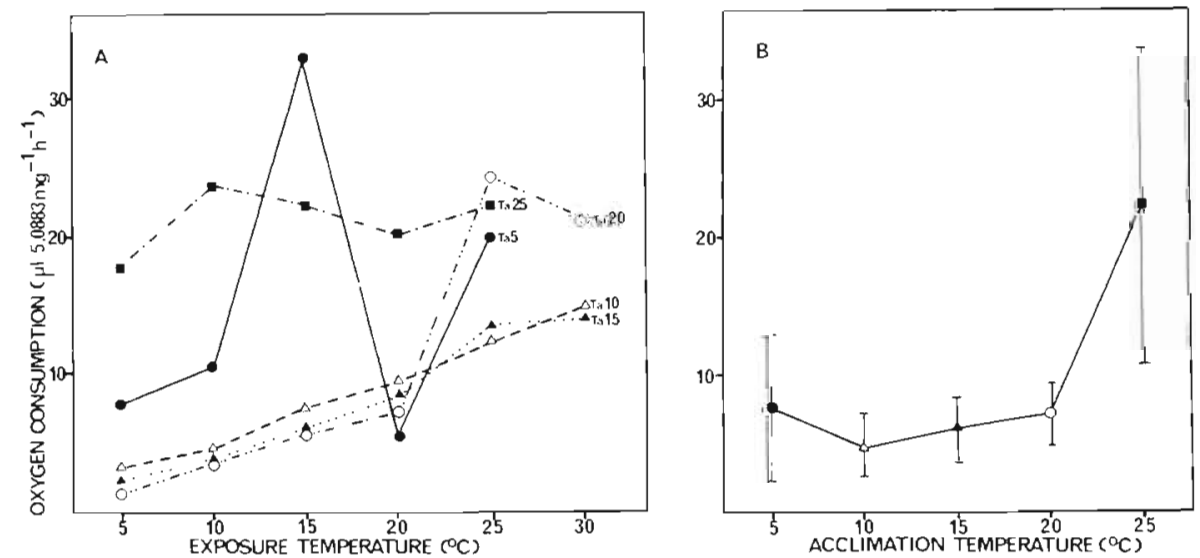

Fig. 3. Ostrea edulis. (A) Filtration efficiency $\left(V_{w} / V_{\mathrm{O}_{2}}\right)$ at different exposure temperatures following acclimation over the range $5^{\circ}$ to $25^{\circ} \mathrm{C}$. (B) Acclimated rate-temperature curve of $V_{w} / V_{O_{2}}$
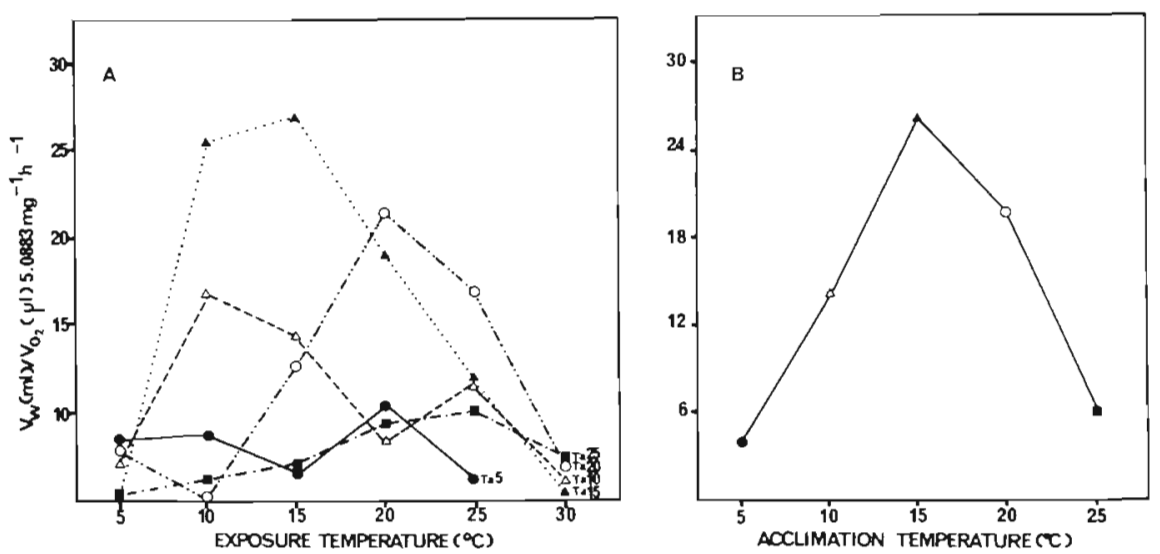
Table 2. Ostrea edulis. Data used for calculation of scope for growth of standard mass oysters (5.0883 mg). Average cell concentration $=15 \times 10^{6}$ cell $1^{-1}$. Energy equivalents based on the following conversion factors: (1) Tetraselmis suecica: $10^{6}$ cells $=1.54 \mathrm{~J}$ (based on Widdows and Bayne, 1971) $=2.7 \mathrm{mg} \mathrm{l}^{-1}$ (Griffiths and King, 1979); (b) Oxycalorific equivalent $=19.85$ $\mathrm{J}$. ml $10_{2} \mathrm{~h}^{-1}$ (Griffiths and King, 1979). Energy losses through excretion were assumed to be negligible and were not included in calculation of scope for growth (p. 74)

\begin{tabular}{|c|c|c|c|c|c|c|c|}
\hline \multirow{2}{*}{$\begin{array}{c}\text { Acclimation } \\
\text { temperature } \\
\qquad\left({ }^{\circ} \mathrm{C}\right)\end{array}$} & \multicolumn{2}{|c|}{ Respiratory rate } & \multirow{2}{*}{$\begin{array}{l}\text { Filtration rate } \\
\qquad\left(\mathrm{m} l \mathrm{~h}^{-1}\right)\end{array}$} & \multicolumn{2}{|c|}{ Ingested ration } & \multirow{2}{*}{$\begin{array}{l}\text { Assimilated ration } \\
\qquad\left(\mathrm{J} \mathrm{h}^{-1}\right)\end{array}$} & \multirow{2}{*}{$\begin{array}{c}\text { Scope for } \\
\text { growth } \\
\left(\mathrm{J} \mathrm{h}^{-1}\right)\end{array}$} \\
\hline & $\left(\mu .1 O_{2} h^{-1}\right)$ & $\left(\mathrm{J} \mathrm{h}^{-1}\right)$ & & $\begin{array}{c}\left(\times 10^{6}\right. \\
\text { cells h } \\
\left.h^{-1}\right)\end{array}$ & $\left(\mathrm{J} \mathrm{h}^{-1}\right)$ & & \\
\hline & $\bar{x}( \pm s . d)$. & & $\bar{x}( \pm s . d)$. & & & & \\
\hline 5 & $7.95 \quad(5.6)$ & 0.16 & $32.37(12.67)$ & 0.49 & 0.76 & 0.53 & 0.37 \\
\hline 10 & $4.65 \quad(2.5)$ & 0.09 & $66.11(14.18)$ & 0.99 & 1.53 & 1.25 & 1.16 \\
\hline 15 & $6.21 \quad(2.5)$ & 0.12 & $162.25(74.30)$ & 2.43 & 3.74 & 3.00 & 2.88 \\
\hline 20 & $7.26 \quad(2.4)$ & 0.14 & $144.57(45.90)$ & 2.17 & 3.33 & 2.52 & 2.38 \\
\hline 25 & $22.30(11.7)$ & 0.44 & $135.00(60.62)$ & 2.03 & 3.12 & 2.26 & 1.82 \\
\hline
\end{tabular}

\section{Scope for Growth}

The 'scope for growth' has been widely used as an index of energy balance in bivalves and other organisms (see Warren and Davis, 1967; Dame, 1972; Bayne et al., 1973; Bayne, 1976); it may be calculated by subtraction of the energy equivalent of oxygen consumption from the assimilated ration. Ingested ration may be calculated from the product of filtration rate

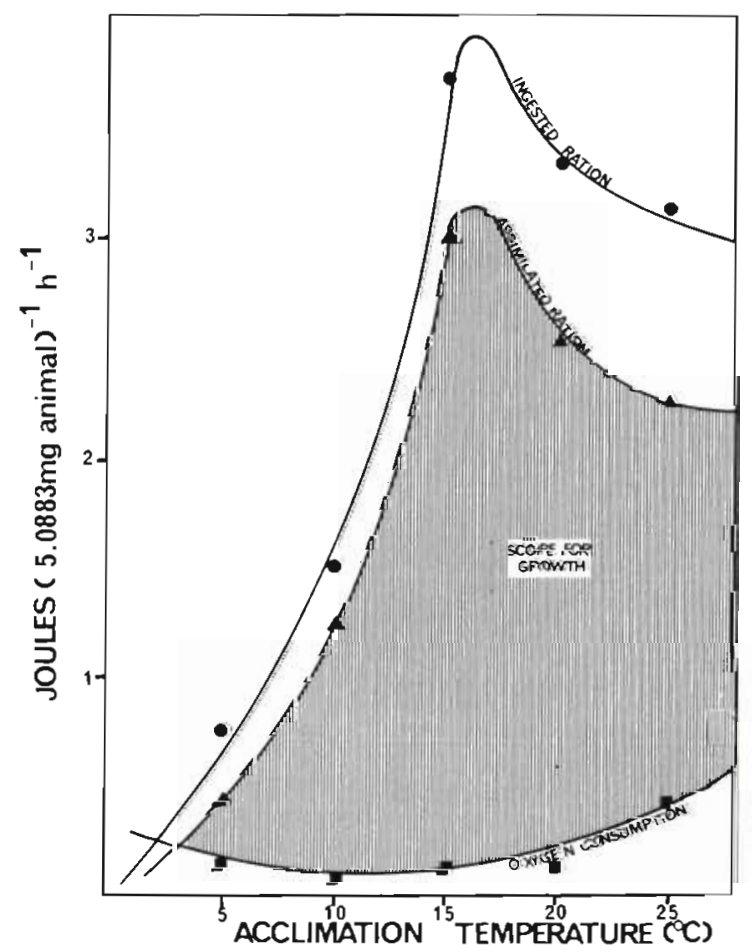

Fig. 4. Ostrea edulis. Effect of thermal acclimation on the ingested ration $(\bullet)$, assimilated ration $(\boldsymbol{\Delta})$, oxygen consumption ( $\boldsymbol{a}$ ) and resultant scope for growth in juveniles (see also Table 2) and food concentration $\left(15 \times 10^{6}\right.$ cells $\left.\mathrm{l}^{-1}\right)$ whilst assimilated ration is obtained from the product of assimilation efficiency and ingested ration.

The values for these are summarised in Table 2 . In larger oysters the net energetic gain represents that available to support production as growth $(\mathrm{Pg})$ and reproduction $(\mathrm{Pr})$. However, as pointed out also by Dame (1972), in small oysters the situation is simplified since all production is channelled into growth. $P g$ thus becomes numerically equivalent to $P$ in juvenile oysters. It is noticeable that scope for growth has a positive index throughout, indicating a surplus of energy available for growth $(P)$ at this ration level. A graphical summary of the influence of acclimation temperature on scope for growth in juvenile Ostrea edulis is shown in Fig. 4 and is very similar to the seasonal cycle in scope for growth in the oyster Crassostrea virginica (Dame, 1972) in which the difference between assimilated ration and respiratory costs reached a maximum during September. The ingested ration increases to a maximum at $15^{\circ} \mathrm{C}$ after which it declines, reflecting the decrease in filtration rate (Fig. 1). Because assimilation efficiency (Table 1) remains relatively unchanged over the range of acclimation temperatures, the assimilated ration follows the same pattern. Scope for growth is indicated by the hatched area which represents the energy gain of assimilation minus the energy expenditure of metabolism.

\section{DISCUSSION}

The results obtained on the influence of short-term exposure temperature and long-term thermal acclimation on filtration rates, assimilation efficiency and oxygen consumption in juvenile Ostrea edulis generally support those obtained for other molluscs, including oysters. Lateral translation of the rate-temperature 
Table 3. Ostrea edulis. Regression equations generated from calculated assimilated ration and oxygen consumption of juveniles following acclimation between $5^{\circ}$ and $25^{\circ} \mathrm{C}$ and short-term exposure to temperatures between $5^{\circ}$ and $30^{\circ} \mathrm{C}$. Terms in each equation are ranked according to their stepwise sequence of entry and are expressed as Joules per standard oyster $h^{-1}$

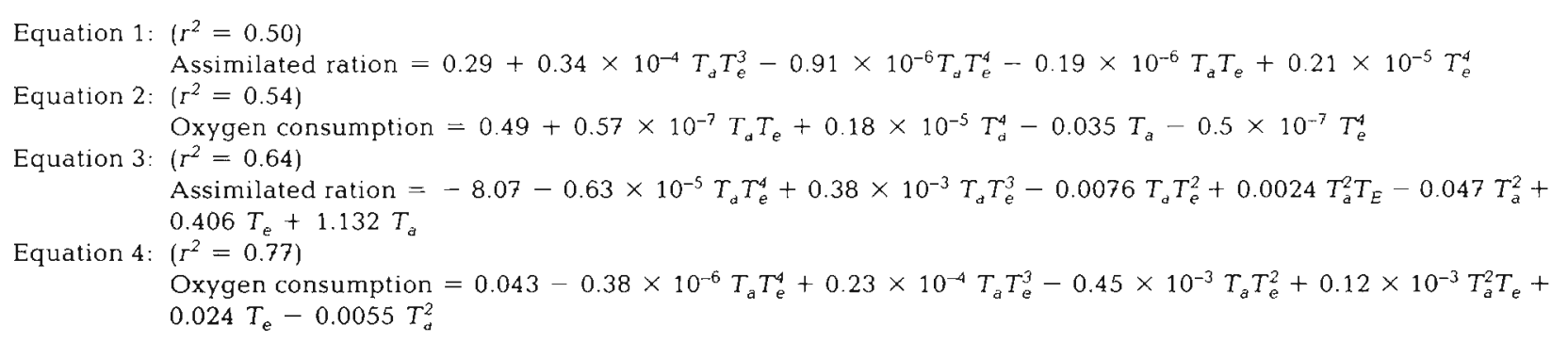

curves for filtration have been reported by Newell and Kofoed (1977 a,b) for the slipper limpet Crepidula fornicata, and by Newell et al. (1977) for large individuals of $O$. edulis, although the extent of translation was more pronounced than in the small oysters used in this study. Lateral translation of curves for routine oxygen consumption ( $V_{O_{1}}$ ) following thermal acclimation have been reported for Mytilus edulis (Bayne et al., 1973; Widdows, 1973a,b; Bayne, 1976). In agreement with the results obtained here, Newell et al. (1977) found little evidence of lateral translation of the curves relating $V_{\mathrm{O}_{2}}$ to exposure temperature in large $O$. edulis, although there was some evidence of rotation following thermal acclimation. In all these examples, however, the result of compensatory adjustment of $V_{O}$. is that oxygen consumption is maintained at a relatively uniform rate over the range of environmental temperatures likely to be experienced by the bivalve.

Compensatory adjustments of the filtration rate and corresponding oxygen consumption lead to an improvement in the ratio of $V_{w} / V_{\mathrm{O}_{2}}$ in Ostrea edulis with warm acclimation, a maximum value of 24.7 being obtained at $15^{\circ} \mathrm{C}$ (Fig. 3B). This value is considerably higher than that obtained by Newell et al. (1977) for large oysters but agrees with values cited for other bivalves (Jørgensen 1966; Vahl, 1973a,b). The 'scope for growth', representing the net energetic gain after respiratory losses have been taken into account, thus approaches a maximum following acclimation to $15^{\circ} \mathrm{C}$, and may be greater in small oysters than large ones, much as reported for mussels by Thompson and Bayne (1974).

Apart from an analysis of the effects of body size, ration and acclimation temperature on scope for growth' in Mytilus edulis by Widdows $(1978 \mathrm{a}, \mathrm{b})$, few studies have attempted to combine the simultaneous effects of a variety of independent variables on the scope for growth in bivalves. Stepwise linear regression analyses of the factors affecting the assimilated ration and oxygen consumption in juvenile Ostrea edulis yielded the multiple regression equations sum- marised in Table 3. Equations (1) and (2) show the regressions obtained for the whole range of experimental data from low exposure temperatures of $5^{\circ} \mathrm{C}$ up to $30^{\circ} \mathrm{C}$. However, the standardised residuals between observed and calculated values of the dependent variables showed that most of the variation between the experimental data and the model occurred at acclimation temperatures of $5^{\circ}$ and $25^{\circ} \mathrm{C}$. This variation is probably associated with thermal stress effects at the extremes of the range of thermal tolerance. Re-entering the data but omitting $T_{d} 5^{\circ}$ and $T_{d} 25^{\circ} \mathrm{C}$ produced Equations (3) and (4) (Table 3), and improved both the coefficients of determination $\left(r^{2}\right)$ and the predictive accuracy of the model. Nevertheless it will be noted that the values for $r^{2}$ are still only 0.64 for the multiple regression equation describing factors affecting assimilated ration and 0.77 for that describing oxygen consumption. We attribute this to the well-known variability in filtration rate and dependent routine oxygen consumption between individuals and with time rather than to an omission in independent variables incorporated into the multiple regression equation. In spite of the relatively low values for $r^{2}$, we have confidence in the predictive value of the equations since it will be noted that the graphs generated from them accord well with the experimental observations summarised in Figs. 1-4.

It is clear from Equation (3) that variation in the assimilated ration in Ostrea edulis may be described by the effects of exposure temperature ( $T_{e}$ ), acclimation temperature $\left(T_{a}\right)$ and by up to fourth order curvilinearity interactions between $T_{e}$ and $T_{d}$. Variations in oxygen consumption (Equation 4. Table 3), on the other hand, are described by first degree terms for $T_{e}$, second degree curvilinearity terms for $T_{a}$, and by up to fifth degree terms for interactions between $T_{a}$ and $T_{e}$. The main feature of importance, however, is that the component terms of the equations are ranked in order of their individual importance in the multiple regression equation (p. 75). These show that in all equations both assimilated ration and oxygen consumption are 
primarily controlled by complex interactions between exposure and acclimation temperature rather than by a simple dependence on either variable.

For the purpose of analysis of the actual data obtained in our experiments we regard as preferable use of Equations (1) and (2) covering the complete range of experimental temperatures from $5^{\circ}$ to $30^{\circ} \mathrm{C}$ and to retain Equations (3) and (4) if necessary for predictive purposes within the acclimation temperature range of $10^{\circ}$ to $20^{\circ} \mathrm{C}$. The response surface derived from Equation (1) is shown in Fig. 5, which summarises the combined effects of short-term exposure temperature $\left(T_{e}\right)$ and acclimation temperature $\left(T_{d}\right)$ on the assimilated ration by Ostrea edulis. It is evident that the maximal assimilated ration is at an acclimation temperature of approximately $22^{\circ} \mathrm{C}$ and an exposure temperature of approximately $25^{\circ} \mathrm{C}$. The corresponding response surface for respiratory losses generated from Equation (2) is shown in Fig. 6. This shows a trough of minimal oxygen consumption over the acclimation range $15^{\circ}$ to $20^{\circ} \mathrm{C}$ and at exposure temperatures up to $30^{\circ} \mathrm{C}$. It is also apparent that metabolic costs increase sharply in oysters acclimated to temperatures above $20^{\circ} \mathrm{C}$ and exposed to short-term thermal stress above $25^{\circ} \mathrm{C}$.

The response surface relating the scope for growth in Ostrea edulis (assimilated ration - energy equivalent of respiratory losses) as a function of acclimation $\left(T_{d}\right)$ and exposure temperature $\left(T_{e}\right)$ is shown in Fig. 7. The model shows that maximum scope for growth occurs at an acclimation temperature $\left(T_{\mathrm{d}}\right)$ of approximately $17^{\circ} \mathrm{C}$ and an exposure temperature $\left(T_{e}\right)$ of approxi-

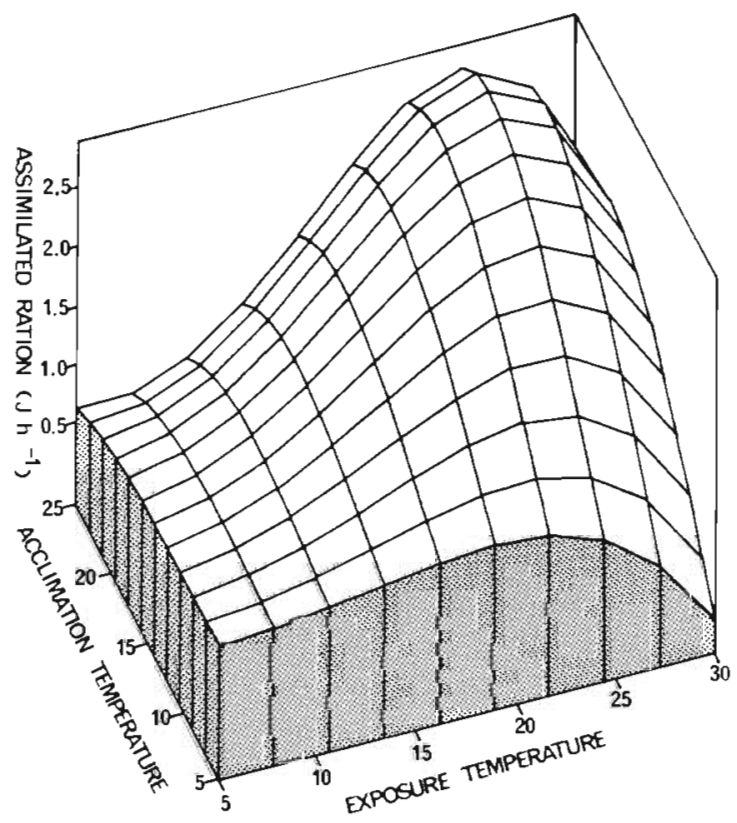

Fig. 5. Ostrea edulis. Response surface relating $T_{\sigma}, T_{0}$ and assimilated rátion (derived from Equation [1], Table 3) mately $25^{\circ} \mathrm{C}$ and thus predicts an increased growth rate during the summer months as a result of the combined effects of temperature on the balance between assimilated ration and metabolic energy expenditure. Clearly, these results closely resemble the increase in growth rate recorded by Dame (1972) for

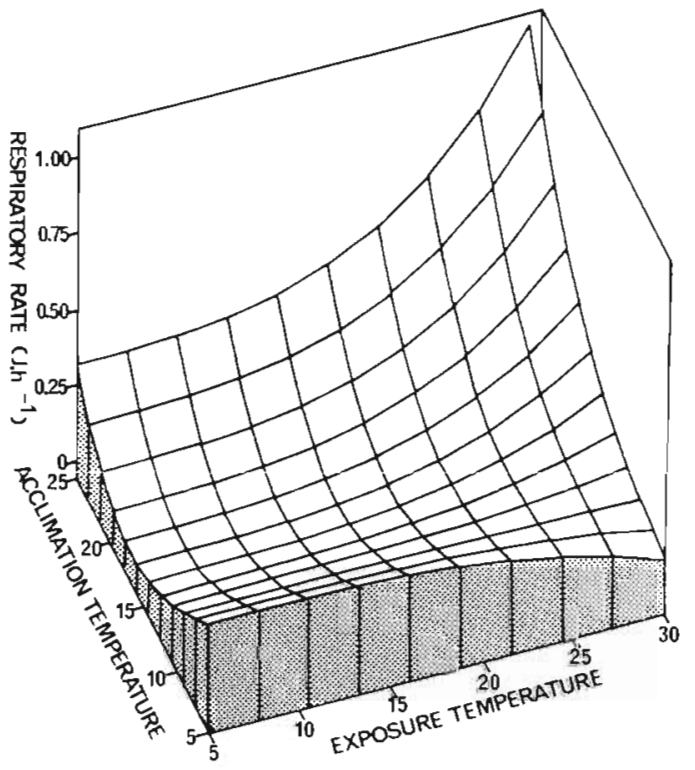

Fig. 6. Ostrea edulis. Response surface relating $T_{a}, T_{e}$ and oxygen consumption (derived from Equation [2], Table 3). A trough extends from $10^{\circ}$ to $30^{\circ} \mathrm{C} T_{e}$ but the data also show a small maximum at $T_{1} 15^{\circ}, T_{\mathrm{e}} 5^{\circ} \mathrm{C}$ not accounted for by the model. This contributes to the error term

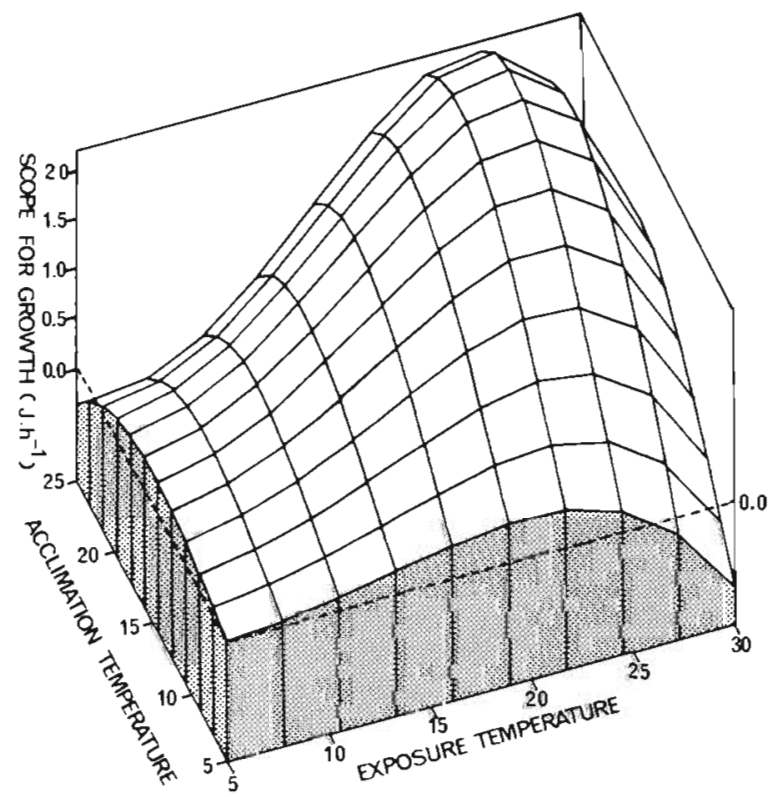

Fig. 7 Ostrea edulis. Response surface summarising the combined effects of acclimation temperature $\left(T_{\alpha}\right)$ and short-term exposure temperature $\left(T_{\mathrm{c}}\right)$ on scope for growth in juveniles (derived from Equations [1] and [2], Table 3) 


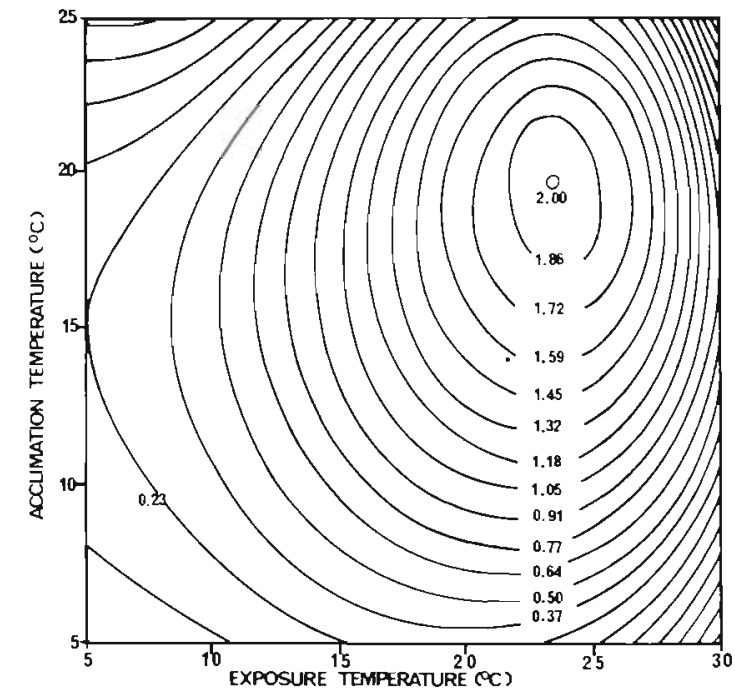

Fig. 8. Ostrea edulis. Scope for growth $\left(\mathrm{J} \mathrm{h}^{-1}\right)$ in juveniles (generated from Equations [1] and [2]. Table 3)

juvenile Crassostrea virginica during the late summer months.

The fact that the maximum scope for growth in Ostrea edulis is attained following warm acclimation to $17^{\circ} \mathrm{C}$ but can be enhanced by short-term exposure to temperatures of approximately $25^{\circ} \mathrm{C}$ is of considerable interest in view of the fact that the oyster commonly thrives in shallow water and mud flat situations. A contour diagram showing the scope for growth generated from Equations (1) and (2) (Table 3) is shown in Fig. 8. This suggests that gradual warm-acclimation during the summer months, coupled with pulses of relatively high exposure temperature of $25^{\circ} \mathrm{C}$, may represent optimal conditions for production by this cyster.

In conclusion, it appears that assimilation efficiency is unaffected by thermal acclimation although both filtration and oxygen consumption are modifiable, the ratio of volume of water filtered per unit oxygen consumed reaching its maximal value between $15^{\circ}$ and $20^{\circ} \mathrm{C}$. As a result of these adjustments in filtration and oxygen consumption following thermal acclimation, filtration efficiency, cost of filtration, assimilated ration and hence scope for growth achieved optimal values following warm acclimation between $15^{\circ}$ and $20^{\circ} \mathrm{C}$. Thus, there are obvious advantages in the maintenance of Ostrea edulis at temperatures between $15^{\circ}$ and $20^{\circ} \mathrm{C}$ for optimal growth in artificial mariculture regimes, whilst short-term increases in temperature up to $25^{\circ} \mathrm{C}$ such as commonly occur in very shallow waters during the summer months, may additionally enhance growth.

Acknowledgements. This work was funded by post-graduate research grants from the Fisheries Development Corporation and the Councll for Sclentific and Industrial Research of South Africa. We thank S. Tolosana and D. Muir for help in preparing manuscript and figures.

\section{LITERATURE CITED}

Alderdice, D. F. (1972). Responses of marıne polkılotherms to environmental factors acting in concert. In: Kinne, $\mathrm{O}$. (ed.) Marine ecology, Vol. 1, Environmental factors, Part 3. Wiley, London, pp. 1599-1722

Allen, J. (1973). Stepreg 1, Stepwise linear regression analysis, University of Wisconsin, Madison

Bayne, B. L. (1976). Marine mussels: their ecology and physjology, Cambridge University Press, Cambridge

Bayne, B. L., Scullard, C. (1978). Rates of oxygen consumption by Thais (Nucella) lapillus. J. exp. mar B1ol. Ecol. 32 (1): $97-111$

Bayne, B. L., Thompson, R. J., Widdows, J. (1973). Some effects of temperature and food on the rate of oxygen consumption by Mytilus edulis L. In: Wieser, W (ed.) Effects of temperature on ectothermic organisms. Springer-Verlag, Berlin, pp. 181-193

Brett, J. R. (1976). Scope for metabolism and growth of sockeye salmon, Oncorhynchus nerka, and some related energetics. J. Fish. Res. Bd Can. 33: 307-313

Brett, J. R. (1979). Environmental factors and growth. Chapter 10. In: Hoar, W. S., Randall, D. J., Brelt, J. R. (e.ds.) Fish physiology 8. Academic Press, London, pp. 599-667

Buxton, C. D. (1980). Energy balance of a laboratory population of Ostrea eduhs (L.). Unpbl. M. Sc. thesis, University of Cape Town

Conover, R. J. (1966). Assimilation of organic matter by zooplankton. Limnol. Oceanogr 11: 338-354

Coughlan, L. (1969). The estimation of filtering rate from the clearance of suspensions. Mar Biol. 35: 79-93

Crisp, D. J., Ritz, D. A. (1967). Temperature acclimation in barnacles. J. exp. mar Biol. Ecol. 1. 236-256

Dame, R. F. (1972). The ecological energies of growth, respiration and assimilation in the intertidal American oyster, Crassostrea virginica. Mar. Biol. 17: 243-250

Fry, F. E. J. (1947). Effects of the environment on anumal activity. Univ. Toronto Stud. Biol. (55) (Publ. Ontario Fish Res. Lab.) 68: 1-62

Fry, F. E. J. (1971). The effects of environmental factors on the physiology of fish. In: Hoar, W. S., Randall, D. J. (eds.) Fish physiology. Academic Press, London, pp. 1-98

Gabbott, P. A. (1975). Storage cycles in marine bivalve molluscs: a hypothesis concerning the relationship between glycogen and gametogenesis. In: Barnes, H. (ed.) Proceedings of 9th European Marine Biological Symposium. Aberdeen University Press, Aberdeen, pp. 191-211

Gabbott, P. A., Bayne, B. L. (1973). Biochemical effects of temperature and nutritive stress on Mytilus edulis (L.). J. mar. biol. Ass. U. K. 53: 269-286

Griffiths, C. L., King, J. A. (1979). Some relationships between size, food availability and energy balance in the ribbed mussel Aulacomya ater. Mar Biol. 51: 141-149

Jorgensen, C. B. (1966). Biology of suspension feeding, Pergamon Press, Oxford

Kinne, O. (1963a). The effects of temperature and salinity on marine and brackish water animals. 1 Temperature. Oceanogr mar Biol. A. Rev. 1: 301-340

Kinne, O. (1963b). Adaptation, a primary mechanism of evolution. In: Whittington, H. B., Rolfe, W D. I. (eds.) 
Museum of Comparative Zoology, Cambridge, Mass., pp. $27-50$

Kinne, O. (1970). Temperature: invertebrates. In: Kinne, O (ed.) Marine ecology, Vol. I, Environmental factors, Part 1. Wiley, London, pp. 407-514

Newell, R. C. (1979). Biology of intertidal animals, 3rd ed. Marine Ecological Survey, Faversham, Kent, U.K.

Newell, R. C. (1980). The maintenance of energy balance in marine invertebrates exposed to changes in environmental temperature. Gilles, R. (ed.) Animals and environmental fitness. (Proc. 1st. Cong. Eur. Soc Comp. Phys. Bioch. Vol. 1) Pergamon Press, London, pp. 561-582

Newell, R. C., Branch, G. M. (1980). The influence of temperature on the maintenance of metabolic energy balance in marine invertebrates. Adv. mar Biol. 17: 329-396

Newell, R. C., Johnson, L. G., Kofoed, L. H. (1977). Adjustment of the components of energy balance in response to temperature change in Ostrea edulis. Oecologia (Berl.) 30: $97-100$

Newell, R. C., Kofoed, L. H. (1977 a). The energetics of suspension feeding in the gastropod Crepidula fornicata L. J. mar. biol. Ass. U. K. 51: 161-180

Newell, R. C., Kofoed, L. H. (1977 b). Adjustment of the components of energy balance in the gastropod Crepidula fornicata in response to thermal acclimation. Mar. Biol. 44 : $275-286$

Odum, H. T., Smalley, A. E. (1959). Comparison of population energy flow of a herbivorous and a deposit-feeding invertebrate in a salt marsh ecosystern. Proc. natn. Acad. Sci. USA 45: 617-627

Petrusewicz, K., MacFadyen, A. (1970). Productivity of terrestrial animals, principles and methods, I. B. P. Handbook (13) Blackwell, Oxford

Precht, H. (1958). Concepts of the temperature adaptations of unchanging reaction systems of cold-blooded animals. In: Prosser C. L. (ed.) Physiological adaptation. Ronald Press Co., New York pp. 50-78

Precht, H., Christophersen, T., Hensel, H., Larcher, W. (1973). Temperature and life, Springer-Verlag, Heidelberg

Ricker, W. E. (1968). Methods for assessment of fish produc- tion in fresh waters, I. B. P. Handbook (3), Blackwell, Oxford

Thompson, R. J., Bayne, B. L. (1974). Some relationships between growth, metabolism and food in the mussel, Mytilus edulis. Mar. Biol. 27: 317-326

Thompson, R. J., Ratcliffe, N. A., Bayne, B. L. (1974). Effects of starvation on structure and function of the digestive gland of the mussel (Mytilus edulis L.). J. mar. biol. Ass. U. K. 54: $699-712$

Vahl, O. (1973a). Porosity of the gill, oxygen consumption and pumping rate in Cardium edule (L.) (Bivalvia). Ophelia 10: $109-118$

Vahl, O. (1973b). Pumping and oxygen consumption rates of Mytilus edulis L. of different sizes. Ophelia 14:45-52

Warren, C. E., Davis, G. E. (1967), Laboratory studies on the feeding, bioenergetics and growth of fish. In: Gerking, $\mathrm{S}$. D. (ed.) The biological basis of freshwater fish production. Blackwell, Oxford, pp. 175-214

Widdows, J. (1973a). Effect of temperature and food on the heart beat, ventilation rate and oxygen uptake of Mytilus edulis. Mar. Biol. 20: 269-276

Widdows, J. $(1973 \mathrm{~b})$. The effects of temperature on the metabolism and activity of Mytilus edulis L. Neth. J. Sea Res. 7: 387-398

Widdows, J. (1978a). Combined effects of body size, food concentration and season on the physiology of Mytilus edulis. J. mar. biol. Ass. U. K. 58: 109-125

Widdows, J. (1978b). Physiological indices of stress in Mytilus edulis. J. mar. biol. Ass. U. K. 58: 125-142

Widdows, J., Bayne, B. L. (1971). Temperature acclimation of Mytilus edulis with reference to its energy budget. $\mathrm{J}$. mar. biol. Ass. U.K. 51: $827-843$

Winberg, G. C. (1956). Rate of metabolism and food requirements of fishes (Russ.). Belorussian State University, Minsk (Transl. Ser. Fish. Res. Bd Can. 194)

Winter, J. E. (1977). Suspension feeding lamellibranchiate bivalves with particular reference to aquaculture. MedioAmbiente 3 (1): 48-69

Zar, J. H. (1974). Biostatistical analysis, Prentice Hall, Engelwood Cliffs, New Jersey 